\title{
Characterization of cellulase from $E$. coli BPPTCC-EGRK2
}

\author{
Mas Gunawan Haryanto ${ }^{1}$, Siswa Setyahadi ${ }^{2}$, Muhammad Sahlan ${ }^{1}$, Masafumi Yohda ${ }^{3}$, \\ Yosuke Fukutani ${ }^{3}$, Eko Agus Suryono ${ }^{4}$, and Misri Gozan ${ }^{1 *}$ \\ ${ }^{1}$ Chemical Engineering Department, Faculty of Engineering, Universitas Indonesia, Depok 16424, \\ Indonesia \\ ${ }^{2}$ Center for Bioindustrial Technology, Agency for Assessment and Application of Technology, 15314 \\ Serpong, Indonesia \\ ${ }^{3}$ Department of Biotechnology and Life Science Tokyo University of Agriculture and Technology 2- \\ 24-16 Naka-cho, Koganei, Tokyo Japan 184-8588 \\ ${ }^{4}$ Faculty of Biology, Gadjah Mada University, Indonesia
}

\begin{abstract}
Cellulase enzymes are widely used in various industries such as detergent industry, bioethanol, animal feed, textile and paper. This research focused on characterization of cellulase produced from Eschericia coli BPPT-CC EgRK2, which is a recombinant that can produce protein enzymes endo- $\beta$-1,4-glucanase. Eschericia coli BPPT-CC EgRK2 was cultured in 1 litre liquid medium Luria Bertani. Because the bacteria is intracellular, sonication is needed for cell disruption to get the cellulase enzyme. The enzyme activity was then analyzed by CMC substrate at different concentration. The protein content analysis was carried out using Bradford method; the molecular weight analysis was done using SDSPAGE; while the enzyme kinetics was plotted using Michaelis-Menten model. Our results showed the highest enzyme activity was $2.403 \mathrm{U} / \mathrm{ml}$ and the protein concentration was $5.352 \mathrm{mg} / \mathrm{ml}$. The Michaelis-Menten constant $(\mathrm{Km})$ and maximum velocity (Vmax) for CMC substrate hydrolysis were $0.07 \mu \mathrm{mol} / \mathrm{ml}$ and $2.49 \mu \mathrm{mol} / \mathrm{ml} / \mathrm{sec}$, respectively. The cellulase molecular weight was $58 \mathrm{kDa}$ using SDS-PAGE with $7.5 \%$ stacking gel. The results indicated that Eschericia coli BPPT-CC EgRK2 is a promising renewable source for cellulase production for industrial application.
\end{abstract}

\section{Introduction}

Enzymes are proteins that function as biocatalysts in a chemical or biological reaction [1]. The enzyme is a protein biomolecule that acts as a catalyst (a compound that speeds the reaction process without reacting) to *an organic chemical reaction. Substrate as the initial molecule will be accelerated its conversion into another molecule called product. The type of product to be produced depends on a condition / substance, called a promoter. The work of enzymes is influenced by several factors, mainly substrate, temperature, acidity, cofactor

\footnotetext{
*Corresponding author: misrigozan@gmail.com
} 
and inhibitor. Each enzyme requires different temperatures and $\mathrm{pH}$ (acidity levels) because different enzymes are proteins, which can change shape if temperature and acidity change.

One of the most widely used enzymes in the industry is the cellulase enzyme. Cellulase can convert cellulose, the main polymer in biomass, into glucose which can be further fermented to ethanol. Cellulase is currently the third largest industrial enzyme worldwide [2]. Cellulase is widely used in biotechnology applications, such as fiber modification in the paper and textile industries, but cellulase also has excellent capabilities in the industrial development of ethanol production from lignocellulose. Cellulase can be used for biomass fermentation into bioethanol [3]. A specific enzyme that is used to degrade cellulose is cellulase enzyme. Enzymatic process in hydrolyzing cellulose is a better and more beneficial way because the surrounding condition for enzyme's activity could be controlled [4].

The conventional method to produce cellulase is by using lignocellulosic fungi such as Aspergillus sp., Trichoderma sp., and Neurospora sp. [5-9]. However, cellulase can also be secreted by bacteria, such as Bacillus sp. Bacteria has a faster growth rate and is genetically easier to recombine compared to fungi [10]. This study examined an E. coli EgRK2 recombinant strain. The recombinant strain was used in this experiment because the result of the previous research showed the wild type has low activity, the recombinant strain grows faster on inexpensive media, ease of isolation and purification of proteins excreted in comparison with the wild type [11].This study examined the effects the enzyme's hydrolysis performance on Carboxymethyl Cellulose (CMC) as the substrate. The aim of the present research is to describe the biosynthesis, isolation and characterization of a cellulase from $E$. coli $E g R K 2$ isolate.

\section{Materials and Methods}

\subsection{Sample Collection}

The research was performed with an inoculum of $E$. coli EgRK2 recombinant strain which obtained from BPPT (Agency for the Assessment and Application of Technology Culture Collection) Laptiab, Puspiptek, Serpong, Tangerang, Indonesia.

E. coli EgRK2 is a recombined product of a Bacillus sp. RK2 isolate. The gene that expressed endo- $\beta$-1.4-glucanase (gene attB-EgRK2) in Bacillus sp. RK2 was isolated and amplified by the Polymerase Chain Reaction (PCR) method.In this study we used GatewayR (Invitrogen) method and two primers such as egrk2F: 5'- AAA AAG CAG GCT CGA TGA AAC GGT CAA TYT Y -3'; egrk2R: 5'- AGA AAG CTG GGT ACT AAT TKG KTT CTG WTC CC -3' and attB1 adapter: 5'- G GGG ACA AGT TTG TAC AAA AAA GCA GGC T -3'; attB2 adapter: 5'- GGG GAC CAC TTT GTA AA GAA AGC TGG GT -3'[11].

These design primers were used for amplifying endonuclease EgRK2 gen from chromosomal of B amyloliquefaciens BPPTCC RK2. pDONR221 as a donor vector with Kanamycin resistance and pDESTI4 as a destination vector with ampicillin resistance. E. coli DH5 $\alpha$ for host cloning and E. coli BL21 Star for expression gen. It was then recombined and expressed in the pEXP-EgRK2 vector, which was transformed to E. coli DH5 $\alpha$ [11]. The isolate was inoculated to Luria-Bertani (LB) slants of agar, and incubated at $37^{\circ} \mathrm{C}$ for $24 \mathrm{~h}$ and used as a culture stock.

\subsection{Cellulase Enzyme Production}


A starter medium was made by inoculating 1 loops of culture stock into sterile $1 \mathrm{~L}$ LB medium, which was previously autoclaved at $121^{\circ} \mathrm{C}$, and 1.2 atm for 2 hours. After autoclaved the LB medium, we put on the rotary shaker at $37^{\circ} \mathrm{C}$ and $150 \mathrm{rpm}$ for 24 hours. Then we centrifuge the medium at $4^{\circ} \mathrm{C}$ and $5000 \mathrm{rpm}$ for 25 minutes. After the pellet and supernatant separate, we add tris- $\mathrm{HCl}$ buffer to the pellet and mixed until homogen. At the end of the process, the culture medium was sonicated for $15 \mathrm{~min}$ to break the cells, and centrifuged at 4,000 rpm for $15 \mathrm{~min}$, to obtain the crude extract that was meant to be used as the enzyme source.

\subsection{Enzyme Assay}

The assay of enzyme activity was done by the DNS (3.5-Dinitrosalicylic Acid) method. The cellulose existence was identified by determining reducing sugar content that was formed as a result of hydrolysis. The enzyme activity calculated using Eq. (1):

$$
\text { Activity }(\mathrm{U} / \mathrm{ml})=\frac{m g \text { glukosa } \times 1000}{\text { Mrglukosa } \times 30 \min \times 0.1 \mathrm{ml}}
$$

DNS method determined the amount of reducing sugar which was formed (mg) as the sugar content; The molar mass of glucose $(180 \mathrm{~g} / \mathrm{mol})$ as Mr reducing sugar, the hydrolysis period of cellulose $(30 \mathrm{~min})$, and the amount of crude extract analyzed as sample $(0.1 \mathrm{~mL})$. Cellulase activity was measured in $\mathrm{U} / \mathrm{mL}$. The amount of enzyme required to liberate 1 $\mu \mathrm{mol}$ of reducing sugar per minute under the assay condition is defined as 1 unit.

The protein content was measured using the Bradford protein assay. An enzyme sample of $2 \mu \mathrm{L}$ was mixed with $795 \mu \mathrm{L}$ aquades and $0.2 \mathrm{~mL}$ Bradford reagent. After that measuring the sample absorbance at $595 \mathrm{~nm}$ wavelength.

\subsection{Enzyme Characterization}

\subsubsection{Gel Electrophoresis}

The determination of cellulose enzyme molecular weight used sodium deodecyl sulphate poly acrylamide gel electrophoresis (SDS-PAGE) with $7.5 \%$ stacking gel at constant current of $20 \mathrm{~mA}$. The following protein calibration kit was used: ovotransferrin $(78 \mathrm{kDa})$, albumin $(66.25 \mathrm{kDa})$, ovalbumin $(45 \mathrm{kDa})$, carbonic anhydhrase $(30 \mathrm{kDa})$. The molecular weight of crude enzyme was determined after gel staining with Comassie Brilliant Blue G250.

\subsubsection{Substrate Specificity and Kinetic Parameters}

To investigate the kinetic paramaters of $\mathrm{CMC}$ as cellulose enzyme substrate, hydrolysis experiments were conducted. Experiments were carried out on CMC $(1 ; 1.25 ; 1.5 ; 1.75$; and $2.0 \%$ wt). The kinetics of CMC degradation by cellulase was evaluated using the Michaelis-Menten model, with linearization using the Lineweaver-Burk approach shown in Eq. (2).

$$
\frac{1}{V o}=\frac{\mathrm{Km}}{\mathrm{Vmaks}} \frac{1}{[\mathrm{~S}]}+\frac{1}{\mathrm{Vmax}}
$$


[S] is the concentration of carbon source $(\mathrm{mg} / \mathrm{mL}), \mathrm{Vmax}$ is the maximum rate of reaction at infinite reactant concentration $(\mu \mathrm{mol} / \mathrm{mL} / \mathrm{sec})$, and $\mathrm{Km}$ is the Michaelis constant $(\mu \mathrm{mol} / \mathrm{mL})$. The $\mathrm{pH}$ condition is 7 and temperature $40^{\circ} \mathrm{C}$.

\section{Results and Discussion}

\subsection{Cellulase Enzyme Activity}

Our study showed that the highest enzyme activity on CMC hydrolysis is $2.403 \mathrm{U} / \mathrm{ml}$ which obtained from 2\% CMC concentration as shown in Fig 1.

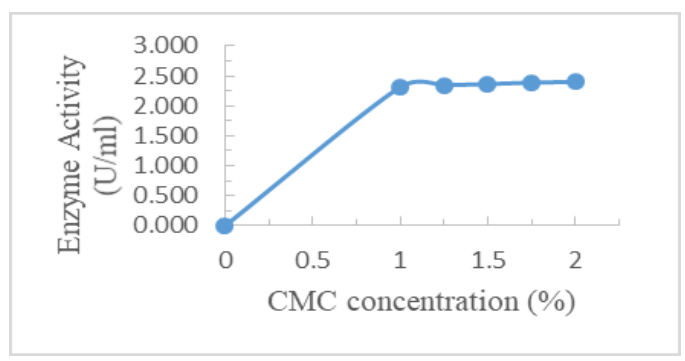

Fig. 1. Cellulase Enzyme activity over different CMC concentration

From this figure we know that reducing sugar concentration gradually increasing during the the substrate is higher. The result of enzyme activity not significantly different from the previous work with CMC as substrate [11] and the optimum condition in this research is $40^{\circ} \mathrm{C}$ for the temperature and 7 for $\mathrm{pH}$ based on the previous work [4] [11]. This result was slightly higher compared to cellulase activity from several studies as shown in figure 2 .

Table 1 The variation of microorganisms for cellulase production

\begin{tabular}{|c|c|c|c|}
\hline Microorganism & Carbon Source & Enzyme activity & Reference \\
\hline E. coli EgRK2 & $\mathrm{CMC}$ & Cellulase - $2.49 \mathrm{U} / \mathrm{mL}$ & This research \\
\hline E. coli EgRK2 & $\begin{array}{l}\text { OPEFB } \\
\text { CMC }\end{array}$ & $\begin{array}{c}\text { Cellulase - } 2.665 \mathrm{U} / \mathrm{mL} \\
\text { Celluase }-2.5 \mathrm{U} / \mathrm{mL}\end{array}$ & [11] \\
\hline $\begin{array}{l}\text { Bacillus sp. RK2 } \\
\text { Bacillus subtilis }\end{array}$ & $\begin{array}{l}\text { OPEFB } \\
\text { CMC }\end{array}$ & $\begin{array}{c}\text { Cellulase }-2.498 \mathrm{U} / \mathrm{mL} \\
\text { Cellulase }-0.9 \mathrm{U} / \mathrm{mL}\end{array}$ & $\begin{array}{l}{[11]} \\
{[12]}\end{array}$ \\
\hline $\begin{array}{c}\text { Bacillus pumilus EB3 } \\
\text { Bacillus pumilus } \\
\text { Neurospora crassa }\end{array}$ & $\begin{array}{c}\text { OPEFB } \\
\text { CMC } \\
\text { Cellulase } \\
\text { Powder } \\
\text { CMC } \\
\text { Wheat Straw }\end{array}$ & $\begin{array}{c}\text { Endoglucanase }-0.076 \mathrm{U} / \mathrm{mL} \\
\text { Endoglucanase }-0.063 \mathrm{U} / \mathrm{mL} \\
\text { Endoglucanase }-0.025 \mathrm{U} / \mathrm{mL} \\
\text { CMCase }-1.9 \mathrm{U} / \mathrm{mL} \text {, cellobiase - } \\
1.2 \mathrm{U} / \mathrm{mL} \\
\text { FPase }-0.667 \mathrm{U} / \mathrm{mL}\end{array}$ & {$[15]$} \\
\hline $\begin{array}{c}\text { Trichoderma ressei } \\
\text { Phenerocheate }\end{array}$ & $\begin{array}{l}\text { Cellulose } \\
\text { Rice straw }\end{array}$ & $\begin{array}{c}\text { FPase }-0.11 \mathrm{U} / \mathrm{mL}, \text { CMCase - } \\
1.05 \mathrm{U} / \mathrm{mL}, \beta \text {-glucosidase }-0.5 \\
\mathrm{U} / \mathrm{mL} \\
\text { FPase }-0.18 \mathrm{U} / \mathrm{mL}, \text { CMCase - } \\
2.00 \mathrm{U} / \mathrm{mL}, \beta \text {-glucosidase }-1.5 \\
\mathrm{U} / \mathrm{mL} \\
\beta \text {-glucosidase }-4.54 \mathrm{U} / \mathrm{mL} \\
\text { FPase }-1.438 \mathrm{U} / \mathrm{mL}\end{array}$ & $\begin{array}{l}{[17]} \\
{[18]}\end{array}$ \\
\hline
\end{tabular}




\begin{tabular}{|c|c|c|c|}
\hline chrysosporium & & & \\
Trichoderma harzianum & OPEFB & FPase $-5.1 \mathrm{U} / \mathrm{g}$ & {$[7]$} \\
Trichoderma ressei & Straw & FPase $-0.041 \mathrm{U} / \mathrm{mL}$ & {$[9]$} \\
Trichoderma koningii & Cellulose & FPase $-1.4 \mathrm{U} / \mathrm{mL}$ & {$[8]$} \\
Trichoderma ressei & Corn stover & CMCase activity $2596.3 \mathrm{IU} / \mathrm{g}$ dry & {$[19]$} \\
\hline
\end{tabular}

The cellulase activity values were $2.665 \mathrm{U} / \mathrm{mL}$ using E. coli EgRK2 and OPEFB as substrate, $2.5 \mathrm{U} / \mathrm{mL}$ using CMC as substrate [11]; $0.041 \mathrm{U} / \mathrm{mL}$ using Trichoderma reesei and straw [9]; $2.00 \mathrm{U} / \mathrm{mL}$ using Chaetomium globusumn and CMC [16]; $1.9 \mathrm{U} / \mathrm{mL}$ using Bacillus pumilus and CMC [14]; $0.063 \mathrm{U} / \mathrm{mL}$ using Bacillus pumilus EB3 using CMC [13]; and $0.9 \mathrm{U} / \mathrm{mL}$ using Bacillus subtilis and $\mathrm{CMC}$ [12].

\subsection{Enzyme Characterization}

\subsubsection{Molecular Weight and Protein Assay}

The crude enzyme from the culture broth was analyzed with SDS-PAGE to know the molecular weight of this protein. Because this crude enzyme was not purified yet, there was still more than one protein band. From the SDS-PAGE we know the molecular weight is 58 $\mathrm{kDa}$. After that we analyzed the protein concentration of this broth. The concentration result is $5.352 \mathrm{mg} / \mathrm{ml}$. This is not concentration of cellulose enzyme, because it is no purified, we can't measure the enzyme concentration.

\subsubsection{Enzyme Kinetics on CMC Hydrolysis}

Cellulase enzyme from Eschericia coli EgRK2 was used to hydrolysis of CMC. CMC degradation experiments showed the Vmax values were $2.49 \mu \mathrm{mol} / \mathrm{mL} / \mathrm{sec}$. The $\mathrm{Km}$ values for $\mathrm{CMC}$ hydrolysis were $0.07 \mu \mathrm{mol} / \mathrm{mL}$ for the recombinant strain. Previous research on $\mathrm{Km}$ and Vmax values which used CMC as substrate have been conducted by using same isolate, Acinetobacter anitratus and Branhamella sp. as shown in Figure 3 [11][20]. In CMC degradation, cellulase from the E. coli EgRK2 had higher Vmax values (2.49 $\mu \mathrm{mol} / \mathrm{mL} / \mathrm{sec})$ compared to two other strains $(0.48$ and $2.56 \mu \mathrm{mol} / \mathrm{mL} / \mathrm{sec}$ for A. anitratus and Branhamella sp., respectively. But had lower Vmax values compared to the previous research with same EgRK2 isolate $(2.543 \mu \mathrm{mol} / \mathrm{mL} / \mathrm{sec})$. Additionally, Vmax values were also higher than cellobiose degradation by using A. anitratus $(0.24 \mu \mathrm{mol} / \mathrm{mL} / \mathrm{sec})$ and Branhamella sp. $(0.34 \mu \mathrm{mol} / \mathrm{mL} / \mathrm{sec})$. Thus the cellulase produced in this research had a better performance value than that produced in other research [20]. The $\mathrm{Km}$ values of cellulase from the E. coli EgRK2 recombinant in CMC degradation $(0.07 \mu \mathrm{mol} / \mathrm{mL})$ were smaller than the cellulase from same EgRK2 isolate in the previous research, A.anitratus $(0.497 \mu \mathrm{mol} / \mathrm{mL})$ and Branhamella sp. $(0.790 \mu \mathrm{mol} / \mathrm{mL})$. Thus in our research the enzyme affinity was better and the carbon source needed to reach its half maximum rate was lower.

Table 2 Values of cellulase Vmax and $\mathrm{Km}$ from various carbon source and microorganism

\begin{tabular}{|c|c|c|c|c|}
\hline $\begin{array}{c}\text { Carbon } \\
\text { Source }\end{array}$ & Microorganism & $\begin{array}{c}\text { Maximum enzymatic } \\
\text { rate, Vmax } \\
(\mu \mathrm{mol} / \mathrm{mL} / \mathrm{sec})\end{array}$ & $\begin{array}{c}\text { Michaelis- } \\
\text { Menten Constant, } \\
\text { Km }\end{array}$ & Reference \\
\hline CMC & E. coli EgRK2 & 2.49 & $0.07 \mu \mathrm{mol} / \mathrm{mL}$ & This research \\
\hline CMC & E. coli EgRK2 & 2.543 & $0.097 \mu \mathrm{mol} / \mathrm{mL}$ & {$[11]$} \\
\hline OPEFB & E. coli EgRK2 & 1.75 & $0.26 \mu \mathrm{mol} / \mathrm{mL}$ & {$[20]$} \\
\hline CMC & $\begin{array}{c}\text { Acinetobacter } \\
\text { anitratus }\end{array}$ & 0.48 & $4.97 \mathrm{mg} / \mathrm{ml}$ & {$[20]$} \\
\hline
\end{tabular}




\begin{tabular}{|c|c|c|c|c|}
\hline & Branhamella $\mathrm{sp}$. & 2.56 & $7.90 \mathrm{mg} / \mathrm{ml}$ & \\
\hline Cellobiose & $\begin{array}{c}\text { Acinetobacter } \\
\text { anitratus } \\
\text { Branhamella } \mathrm{sp} .\end{array}$ & 0.24 & $0.32 \mathrm{mM}$ & {$[20]$} \\
& 0.34 & $2.50 \mathrm{mM}$ & {$[20]$} \\
\hline
\end{tabular}

\section{Conclusion}

Our research shows that cellulase production by the E. coli EgRK2 had Vmax value for CMC degradation were $2.49 \mu \mathrm{mol} / \mathrm{mL} / \mathrm{sec}$, while $\mathrm{Km}$ values were $0.07 \mu \mathrm{mol} / \mathrm{mL}$. The molecular weight was $58 \mathrm{kDa}$ and the protein concentration wa $5.352 \mathrm{mg} / \mathrm{ml}$. This research demonstrated a possible way to develop an efficient hydrolysis system for CMC using $E$. coli EgRK2. The result of this research have known that E. coli EgRK2 become a promising renewable source for cellulase enzyme for industrial application.

\section{Acknowledgements}

Authors are grateful for the financial support provided by Japan Student Service Organization (JASSO), research facilities provided by Tokyo University of Agriculture and Technology and conference funding from USAID through SHERA program- Center for Development of Sustainable Region (CDSR). Authors also gratefully acknowledge for the Center of Bioindustrial Technology, the Agency for Assessment and Application of Technology (BPPT), Indonesia, for their kind technical support.

\section{References}

1. H.S. Fogler, Elements of Chemical Reaction Engineering. 4th ed, pp. 394-418. (Prentice-Hall International, Inc, New Jersey, USA ,2006).

2. M. Gozan, M. Edita, D. H. Park, and P. Bambang Cellulase Immobilization Using Reversible Soluble-Insoluble Polymer. International Journal of Pharma and Bio Sciences. ISSN 0975-6299 (2011)

3. S. Coseri, Cellulose: To depolymerize... or not to?. Biotechnology advances, 35(2), 251-266, (2017)

4. M. Gozan, M.B. Agung., S. Siswa. Variation of C/N Ratio and Fermentation Time In Respone Surface Methodology For Cellulase Production from Bacillus sp. BPPT CC RK2. International Journal of Pharma and Bio Sciences. ISSN 0975-6299 (2013)

5. M. Romero, J. Aguado, L. Gonzalez, and M. Ladero. Cellulase production by Neurospora crassa on wheat straw. Enz. Microb. Technol. 25: 244-250 (1999).

6. S. Wen, C.Z. and W. Liao. Production of cellulase/ $\beta$-glucosidase by the mixed fungi culture of Trichoderma reesei and Aspergillus phoenicis on dairy manure. Proc. Biochem. 40: 3087- 3094 (2005).

7. M.Z. Alam, A.A. Mamun, I.Y. Qudsieh, S.A. Muyibi, H.M. Salleh, and N.M. Omar. Solid state bioconversion of oil palm empty fruit bunches for cellulase enzyme production using a rotary drum bioreactor. Biochem. Eng. J. 46: 61-64 (2009).

8. Z. Wang, H.X. Ong, and A. Geng Cellulase production and oil palm empty fruit bunch saccharification by a new isolate of Trichoderma koningii D-64. Proc. Biochem. 47: 1564-1571 (2012). 
9. V. Rosyida, A.W. Indrianingsih, R. Maryana, and S.K. Wahono. Effect of temperature and fermentation time of crude cellulase production by Trichoderma Reesei on straw substrate. Energy Procedia. 65: 368-371 (2015).

10. M. Maki, K.T. Leung, and W. Qin. The prospects of cellulase-producing bacteria for the bioconversion of lignocellulosic biomass. Int. J. Biol. Sci. 5: 500-516 (2009).

11. S.Z. Amraini, P.A. Lina, H. Heri., S. Siswa., F.R. Siti., D.H. Park., G. Misri. Production and Characterization of Cellulase From E. coli EgRK2 Recombinant Based on Oil Empty Fruit Bunches. The Korean Society for Biotechnology and Bioprocess Engineering and springer. 22:287-295 (2017).

12. S. Sethi, A. Datta, B.L. Gupta, and S. Gupta. Optimization of cellulose production from bacteria isolated from soil. ISRN Biotechnol. 2013: 985685 (2013)

13. H. Ariffin, N. Abdullah, M.S. Kalsom, Y. Shirai, and M.A. Hassan. Production and characterization of cellulose by Bacillus pumilus EB3. Int. J. Eng Technol. 3:47-53 (2006).

14. O.S. Kotchoni, O.O. Shonukan, and W.E. Gachomo. Bacillus pumilus BpCRI 6, a promising candidate for cellulose production under conditions of catabolite repression. Afr. J. Biotechnol. 2: 140-146 (2003).

15. M. Romero, J. Aguado, L. Gonzalez, and M. Ladero Cellulase production by Neurospora crassa on wheat straw. Enz Microb. Technol. 25:244-250 (1999).

16. U. Kalsom, M.S., A.B. Ariff, and H.S. Zulkifli. The treatment of palm empty fruit bunch fibre for subsequent use as substrate for cellulose production by chaetomium globosum kunze. Bioresour. Technol. 62: 1-9 (1997).

17. C. Li, Z Yang., R.H.C. Zhang, D. Zhang, S. Chen, and L. Ma. Effect of pH on cellulose production and morphology of Trichoderma reesei and the application in cellulosic material hydrolysis. J. Biotechnol. 168: 470-477 (2013).

18. M.M.H. Khan, S. Ali, A.F. Razi and M.Z. Alzam. Use of fungi for the bioconversion of rice straw into cellulose enzyme. J. Biotechnol. 168: 470-477 (2007).

19. H. Chen, Q. He, and L. Liu. Cellulase production from the corn stover fraction based on the organ and tissue. Biotechnol. Bioproc. Eng. 16: 867-874 (2011).

20. M.M. Ekpergin. Preliminary studies of cellulase production by Acinrtobacter anitratus and Branhamella sp.Afr. J. Biotechnol. 6: 28-33 (2007). 